\title{
Invited review: Hispanic-style cheeses and their association with Listeria monocytogenes
}

\author{
L. A. Ibarra-Sánchez, ${ }^{1}$ M. L. Van Tassell, ${ }^{1}$ and M. J. Miller ${ }^{2}$ \\ Department of Food Science and Human Nutrition, University of Illinois, Urbana 61801
}

\begin{abstract}
The rise in consumption of Hispanic-style cheeses (HSC), due in large part to the increasing Hispanic population in the United States, has not been met with advances in food safety sufficient to prevent the numerous outbreaks and recalls due to Listeria monocytogenes. Hispanic-style cheeses are typically high moisture and have low salt content and low acidity from being subjected to little to no ripening. These conditions necessitate refrigeration to maintain safety and quality, as the majority of traditional extrinsic preservation methods are either ineffective or disrupt the mild sensory attributes of HSC. Unfortunately, the cold-growth of L. monocytogenes presents significant problems from post-pasteurization contamination or insufficient pasteurization. In this review, we discuss the factors affecting listerial contamination and growth in HSC, and present current knowledge of L. monocytogenes incidence in manufacturing settings and commercial prevalence. Furthermore, we differentiate HSC types by processing methods to aid with interpretation of works involving nonstandardized varieties and, finally, summarize research on intervention methods for eliminating listerial contaminants in HSC.
\end{abstract}

Key words: Mexican-style cheese, Listeria monocytogenes, food safety, antimicrobials

\section{INTRODUCTION}

Across the world, cheeses are consumed in numerous styles and broadly acknowledged for their nutritional value. About one-third of the milk produced in United States is used for cheese production, which is reflected in the broad variety of cheese varieties made in the United States, including American types, Italian types, Muenster, Swiss, and Hispanic-style cheeses (HSC; USDA-NASS, 2015). Hispanic-style cheeses

\footnotetext{
Received October 6, 2016.

Accepted December 14, 2016.

${ }^{1}$ These authors contributed equally to this manuscript.

${ }^{2}$ Corresponding author: mille216@illinois.edu
}

in particular, a category of cheeses referring to those originally developed and manufactured in Mexico and Latin America (Van Hekken et al., 2007), have been increasing in popularity among US consumers over the last 2 decades (Hnosko et al., 2009), which is reflected in the rise in both production and consumption. The HSC have shown an increase in production of $271 \%$ and increase in per capita consumption of $188 \%$ compared with that in 1996, a growth rate at least 3.5-fold higher than observed for Italian type cheeses, the largest cheese group produced and consumed in the United States (USDA-NASS, 1997, 2016; USDA-ERS, 2015). This trend is likely driven in large part by the growing Hispanic population in the United States, which increased 93.7\% between 1996 and 2014, representing an estimated $17 \%$ ( 55 million persons) of the US population (US Census Bureau, 1997, 2015). However, the appreciation for HSC is not limited to Hispanic or Latin populations; the remarkable potential for its consumption by non-Hispanic consumers in the United States has been previously suggested (Clark et al., 2001).

The rise of consumption and production of $\mathrm{HSC}$ is expected to continue in the years to come, which has increased the need for proper awareness of the microbial safety concerns of this group of cheeses. It is well known that nonripened cheeses, such as fresh HSC, are prone to foodborne pathogen contamination, notably with Listeria monocytogenes. However, most HSC safety research has focused on Queso Fresco, leaving other commercially available varieties unaddressed (Torres-Llanez et al., 2006). Combined with the lack of identity standards for HSC in the United States, this has made it difficult to assess the listeriosis risks of other varieties and there has been no comprehensive assessment of L. monocytogenes-associated food safety risk between varieties of HSC.

This is unfortunate, considering the severity of listeriosis and its effect on public health. Infections by $L$. monocytogenes can develop into serious complications, including pneumonia, bacteremia, meningitis, or uterine infections that may result in miscarriage or stillbirth. Although listeriosis is rare, its high fatality rate among young, elderly, pregnant, or otherwise immunocompro- 
mised individuals has led the United States to declare L. monocytogenes 1 of 3 zero-tolerance microorganisms in ready-to-eat foods such as HSC. Listeria constitutes the greatest source of disease burden in dairy foods, with costs due to medical expenses, productivity loss, and mortality estimated to be between $\$ 60$ million and $\$ 2$ billion annually (Batz et al., 2012). The majority of dairy-associated listeriosis cases have been linked to HSC and soft-ripened cheeses (Batz et al., 2011). Costs borne by the dairy industry from recalls and outbreaks are unknown; however, individual outbreaks of pathogens in other foods have each been estimated to trigger hundreds of millions of dollars in nonmedical economic losses as well (Hussain and Dawson, 2013).

\section{TYPES OF HISPANIC-STYLE CHEESES}

Hispanic-style cheeses comprise a large and diverse group, albeit generally unstandardized. At least 30 different varieties are recognized in countries such as Mexico (Villegas de Gante, 2004). Currently there are 63 HSC-producing plants in the United States (USDANASS, 2015), manufacturing varieties including, but not limited to, Queso Fresco, Cotija, Oaxaca, Panela, Chihuahua, Queso Blanco, Asadero, Añejo, Manchego, Adobera, and Ranchero (CMAB, 2016). The HSC show considerable variation in shape, size, texture, moisture, and flavor due to differences in cheesemaking procedures such as curd setting methods, pressing, and ripening (Villegas de Gante, 2004). For further information on characteristics and production aspects of artisan cheeses most commonly produced in Mexico, see González-Córdova et al. (2016). Generally, HSC are characterized by their high moisture and are consumed shortly after manufacture. To help better understand the subtleties differentiating them, Figure 1 delineates several major processing steps that result in 11 select HSC types. The diversity among HSC allows for several ways to classify them but, for practical purposes, these cheeses can be divided into 2 main groups according to their degree of ripening: fresh and aged.

\section{Fresh Hispanic-Style Cheeses}

Most of the HSC are fresh (unripened), generally characterized by being soft, high moisture, having a mild fresh milk flavor, and being ready for consumption immediately after manufacture (e.g., Queso Fresco, Queso Blanco, Panela, and Ranchero). Moreover, pasta filata varieties (e.g., Oaxaca, Asadero, and Adobera), which involve kneading or stretching the curds much like mozzarella, are also considered fresh cheeses. As with all cheeses, HSC undergo varied manufacturing processes that differentiate styles and that may or may not include a light "cook" step, curd milling, kneading, or pressing. Distinctive characteristics and manufacturing properties of these cheeses are summarized in Table 1.

\section{Aged Hispanic-Style Cheeses}

Aged HSC are hard or semi-hard cheeses subjected to ripening, leading to some degree of biochemical transformation of the curd, which affects numerous sensory characteristics. The degree of ripening of aged HSC is usually less than $1 \mathrm{mo}$, matching the preference of Hispanic consumers. Further description of distinguishing characteristics of prototypical aged HSC are outlined in Table 2. Aging of these cheeses, although less extensive than that of other aged varieties, may contribute to fewer food safety concerns than with fresh HSC, due to decreases in moisture content and $\mathrm{pH}$.

\section{FOOD SAFETY}

Several steps can influence pathogen contamination, survival, or growth during manufacture of HSC. The source and microbial quality of milk, adjustment of fat content, milk homogenization, pasteurization, use of starter cultures, coagulation, extensive curd manipulation, hand stirring, salting, whey removal, milling, molding, and storage conditions may all contribute to increase the probabilities of cheese contamination (Ryser, 2007; Fernandez Escartin, 2008).

Traditionally, consumer preferences in Hispanic populations have led to a large proportion of HSC being made from raw milk (Villegas de Gante, 2004; TorresVitela et al., 2012), which may contain pathogens such as Salmonella, Escherichia coli, and Listeria monocytogenes (FDA, 2015). Consumption of raw-milk fresh cheeses constitutes a significant public health threat, evidenced by the number of outbreaks and recalls due to foodborne pathogen contamination.

Foodborne outbreaks caused by consumption of various cheeses have been tied to Salmonella spp., Staphylococcus aureus, E. coli $\mathrm{O} 157: \mathrm{H} 7$, and L. monocytogenes (Gould et al., 2014). It is recognized that HSC provide favorable conditions to support the growth or survival of several foodborne pathogens, including Campylobacter spp., E. coli O157:H7, Salmonella spp., and L. monocytogenes, and their consumption has even caused illness due to norovirus infection. However, with the exception of L. monocytogenes, HSC consumption represents no more than 0.02 to $0.5 \%$ of the outbreaks due to these pathogens (CDC, 2015a). However, about 1 of every 5 listeriosis outbreaks have been traced to HSC (CDC, 2015a), highlighting the fact that such fresh cheeses support L. monocytogenes growth to high levels, as 


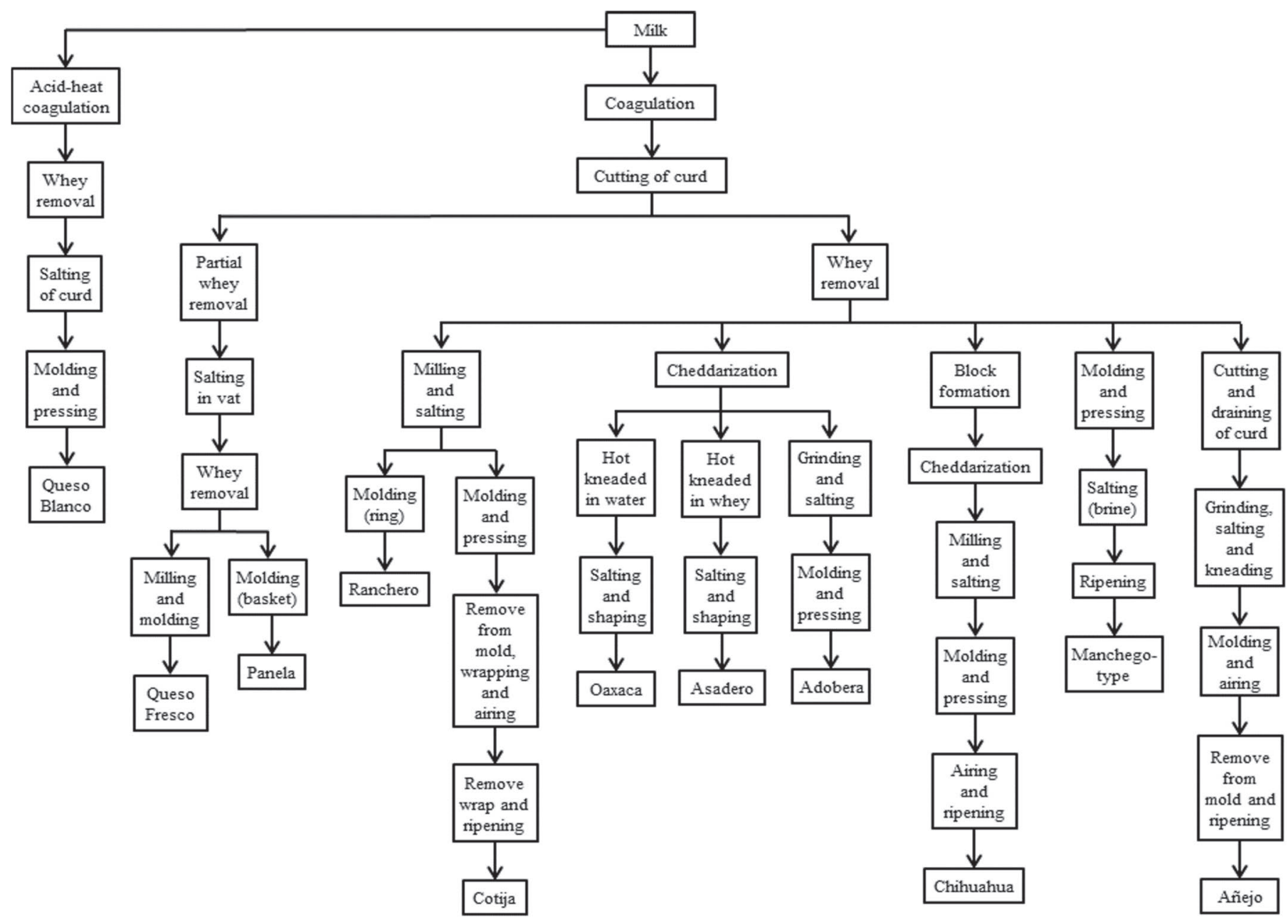

Figure 1. Main cheese-making steps for manufacturing Hispanic-style cheeses.

refrigeration is generally the only post-manufacturing hurdle to pathogen growth (ILSI, 2005).

\section{Physicochemical Characteristics as Risk Factors for L. monocytogenes}

Listeria monocytogenes is able to survive in or on several food products and can grow as long as the conditions provided in the food matrix are favorable. Based on published data, fresh HSC that support the growth of L. monocytogenes include Queso Fresco (Genigeorgis et al., 1991a; Leggett et al., 2012; Van Hekken et al., 2012; Leong et al., 2014; Van Tassell et al., 2015), Queso Blanco (Uhlich et al., 2006; Leong et al., 2014), Panela, and Ranchero (Genigeorgis et al., 1991a). Often some pasta filata cheeses, such as Oaxaca, are considered low risk for pathogen carriage due to manipulation in hot water during manufacturing (thermoplastification). However, laboratory stud- ies have shown that thermoplastification in water at $70^{\circ} \mathrm{C}$ is insufficient to kill food-borne pathogens such as Salmonella, E. coli O157:H7, and L. monocytogenes when pasteurized milk inoculated with those pathogens is used for Oaxaca cheese manufacturing (Fernandez Escartin, 2008).

Regarding aged HSC, Chihuahua and Manchego have been shown to allow survival of $L$. monocytogenes during manufacture and ripening, but they did not support its growth (Solano-López and Hernández-Sánchez, 2000). The pathogen was unable to initiate growth in Cotija cheese in a laboratory study (Genigeorgis et al., 1991a). However, the minimal ripening subjected to some commercial Cotija (Villegas de Gante, 2004), in contrast to genuine Cotija, may increase the risk for survival of L. monocytogenes.

The survival or growth of L. monocytogenes in or on different fresh or aged HSC is not surprising considering their gross physicochemical composition. Fresh 
IBARRA-SÁNCHEZ ET AL.

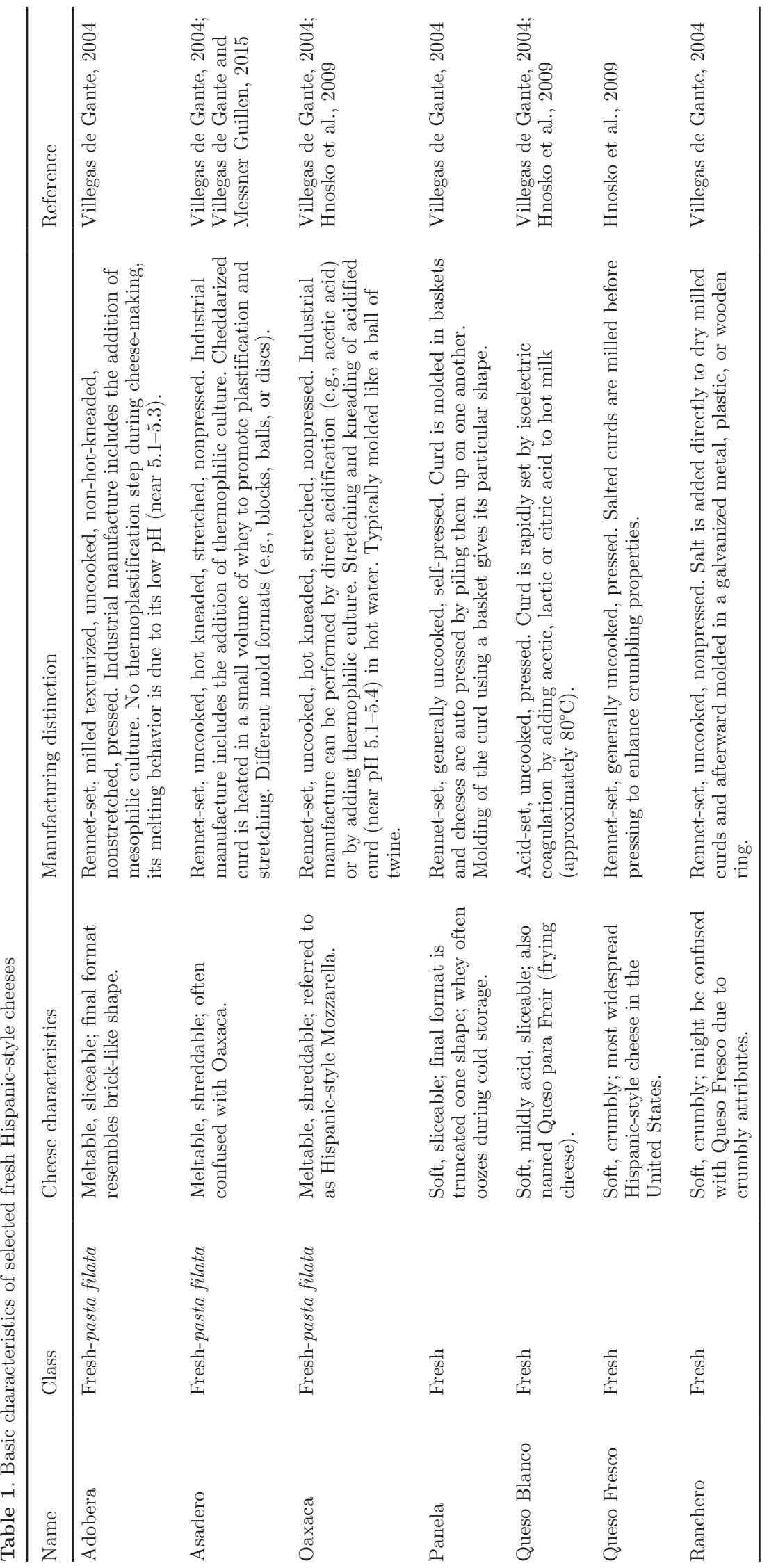


HSC are characterized by their high moisture, salt content as low as $1 \%$ and not greater than $3 \%$, and near neutral pH (Table 3). Conversely, aged HSC have mid-level moisture, salt content similar to that of fresh cheeses or, in the case of Cotija cheese, slightly higher than $4 \%$, and generally have $\mathrm{pH}$ no lower than 5.0 due to their short ripening periods. Additionally, both fresh and aged cheeses require storage at refrigeration temperature. Listeria monocytogenes is capable of growth in a wide range of temperatures $\left(1\right.$ to $\left.45^{\circ} \mathrm{C}\right)$ and $\mathrm{pH}$ (4.1 to 9.6 ), is tolerant of relatively harsh conditions such as high salt concentrations $(10 \%)$, and can grow in the presence of numerous antimicrobial agents (Adzitey and Huda, 2010). As such, even under refrigeration, physicochemical properties of HSC contribute to increased L. monocytogenes-associated food safety risk.

\section{Prevalence of L. monocytogenes in Hispanic-Style Cheeses and in Processing Plants}

The prevalence of L. monocytogenes in commercial or handcrafted HSC varieties is not well understood. This is especially true in the United States, because the limited research into such prevalence has been largely conducted in Mexico (Table 4), where poor epidemiological surveillance also limits comparability of the listerial food safety landscape between countries (Castañeda-Ruelas et al., 2014). The presence of the pathogen has been documented in finished products and marketed cheese samples, showing greater prevalence in fresh cheeses, especially in handcrafted cheeses, although in some aged cheeses sampled (Chihuahua and Manchego), L. monocytogenes was not recovered (Table 4). It is important to highlight that only a small portion of HSC varieties have been investigated in surveys of L. monocytogenes in Mexico. In addition, US surveys have focused on detecting the presence of $L$. monocytogenes in Queso Fresco or HSC as a group, without distinguishing varieties commercially produced, leading to uncertainty in whether all HSC possess similar risk of $L$. monocytogenes contamination.

The presence of $L$. monocytogenes in HSC at the retail level has clear relevance in the aforementioned published surveys; however, studies that have investigated listerial prevalence in HSC processing facilities are scarce. Results have suggested that L. monocytogenes contamination occurs predominantly through post-processing steps (Table 5). One study conducted in New York City found that although isolation frequencies varied between 3 Latin-style fresh-cheese processing plants, L. monocytogenes could be isolated from drains, floors, and crates in all plants (Kabuki et al., 2004), suggesting that the multiple functions of crates (transportation of pasteurized milk and finished prod- 
Table 3. Composition and $\mathrm{pH}$ values of selected Hispanic-style cheeses

\begin{tabular}{|c|c|c|c|c|c|c|}
\hline Cheese variety & Moisture (\%) & Protein (\%) & Fat $(\%)$ & $\mathrm{NaCl}(\%)$ & $\mathrm{pH}$ & Reference \\
\hline Adobera & 47 & 23.4 & 22.5 & $\mathrm{NA}^{1}$ & $4.98-7.3$ & $\begin{array}{l}\text { Villegas de Gante, 2004; Torres- } \\
\text { Vitela et al., } 2012\end{array}$ \\
\hline Añejo & $31.8-41.9$ & $21.44-30.3$ & $25-33.8$ & $1.8-2.8$ & $5.1-5.4$ & Hernández-Morales et al., 2010 \\
\hline Chihuahua & $35.14-42.4$ & $22.1-27.3$ & $27.3-37$ & $0.78-2.18$ & $5.19-5.42$ & $\begin{array}{l}\text { Saltijeral et al., 1999; Van Hekken } \\
\text { et al., 2007; Olson et al., } 2011\end{array}$ \\
\hline Cotija & $37.3-38.2$ & $28.2-28.5$ & $24-25$ & $4.11-4.63$ & $5.20-5.65$ & Villegas de Gante, 2004 \\
\hline Panela & $49-59.4$ & $16.24-20.56$ & $15.44-22.16$ & $1.03-2.13$ & $4.92-6.53$ & $\begin{array}{l}\text { Saltijeral et al., 1999; Torres- } \\
\text { Vitela et al., 2012; Caro et al., } \\
2014\end{array}$ \\
\hline Queso Blanco & $47.02-50$ & $19.6-25$ & $18.2-24.31$ & $2.32-3.3$ & $5.2-6.8$ & $\begin{array}{l}\text { Villegas de Gante, 2004; Uhlich et } \\
\text { al., 2006; Leong et al., } 2014\end{array}$ \\
\hline Queso Fresco & $49.4-58.9$ & $14-19.7$ & $20.5-31$ & $1.02-2.7$ & $5.26-6.77$ & $\begin{array}{l}\text { Tunick and Van Hekken, 2010; } \\
\text { Leggett et al., 2012; Tunick et al., } \\
\text { 2012; Van Hekken et al., 2012, } \\
2013\end{array}$ \\
\hline
\end{tabular}

${ }^{1} \mathrm{NA}=$ data not available.

uct, and storage of finished products in cooler rooms) may contribute to the spread of contaminants from different areas within the plant.

Other studies conducted in Mexico have tracked the presence of L. monocytogenes through the cheesemaking process and environment, across milk samples, processing plants, and retail samples, and suggest that food contact surfaces likely constitute recurrent sources of contamination more commonly than raw or improperly pasteurized milk (Moreno-Enriquez et al., 2007; Rosas-Barbosa et al., 2014). Listeria monocytogenes strains were isolated from milk and curd tanks, utensils, baskets, cheese molds, refrigerators, brooms, and other handling surfaces. In positive cheese samples (Panela,
Queso Fresco, and Adobera), common outbreak serovars $1 / 2 \mathrm{a}, 1 / 2 \mathrm{~b}$, and $4 \mathrm{~b}$ were found, suggesting that consumption of these cheeses may increase the risk of listeriosis (Rosas-Barbosa et al., 2014). These studies illustrate that contamination at the processing level represents an important source of $L$. monocytogenes regardless of the pasteurization status of the milk used for making HSC.

Indeed, it has become clear that L. monocytogenes persistence in food-associated environments contributes significantly to the prevalence of contaminated food products, recalls, and listeriosis outbreaks (Ferreira et al., 2014). Whole-genome sequencing has become invaluable in US listeriosis outbreak investigations, pro-

Table 4. Prevalence of Listeria monocytogenes in some types of Hispanic-style cheeses in Mexico (MX) and the United States (US)

\begin{tabular}{lccl}
\hline \multirow{2}{*}{ Cheese variety } & $\begin{array}{c}\text { Prevalence } \\
\text { (positive samples/total samples) }\end{array}$ & Country & Reference \\
\hline Adobera & $12 \%(12 / 100)$ & MX & Torres-Vitela et al., 2012 \\
Chihuahua & $18.75 \%(3 / 16)$ & MX & Rosas-Barbosa et al., 2014 \\
& $0 \%(0 / 40)$ & MX & Saltijeral et al., 1999 \\
Manchego type & $0 \%(0 / 60)$ & MX & Alcázar Montañez et al., 2006 \\
Panela & $0 \%(0 / 40)$ & MX & Saltijeral et al., 1999 \\
& $15 \%(6 / 40)$ & MX & Alcázar Montañez et al., 2006 \\
Queso Fresco & $0 \%(0 / 60)$ & MX & Torres-Vitela et al., 2012 \\
& $6 \%(6 / 100)$ & MX & Rosas-Barbosa et al., 2014 \\
Hispanic-style cheese, variety unspecified & $37.5 \%(6 / 16)$ & US & MSDA-FSIS, 2003 \\
& $2.75 \%(48 / 1,746)$ & MX & Motono-Enriquez et al., 2007 \\
& $3.4 \%(5 / 149)$ & MX & Rosas-Barbosa et al., 2014 \\
& $9.3 \%(7 / 75)$ & US & Genigeorgis et al., 1991b \\
& $2 \%(25 \%(1 / 16)$ & US & Gombas et al., 2003 \\
& $0.17 \%(5 / 2,931)$ & US & Kabuki et al., 2004
\end{tabular}


viding significantly greater epidemiological resolution relative to prior methods and allowing for enhanced tracing of foodborne illness back to specific manufacturers (Jackson et al., 2016). Subtyping isolates from the processing environment via whole-genome sequencing could help differentiate sporadic isolates from persistent strains that may pose recurring problems and identify associated process deviations or sources responsible for their introduction to final products (Stasiewicz et al., 2015). To our knowledge, such an approach has yet to be implemented within manufacturing facilities for the identification of persistent contaminants in HSC but could inform intervention strategies for targeting their sources.

Additionally, it is unclear to what extent consumer contamination of HSC contributes to foodborne illness; however, poor food storage and handling, combined with the prevalence of pathogens such as $L$. monocytogenes in home refrigerators, undoubtedly contributes in some capacity (Kilonzo-Nthenge et al., 2008; MacíasRodríguez et al., 2013). Consumer handling of readyto-eat foods, particularly improper storage, is a known contributor to elevated risk of foodborne listeriosis (Yang et al., 2006), and susceptibility of HSC to further listerial growth during storage suggests that additional hurdles should be implemented to account for this risk.

\section{Listeriosis Outbreaks Associated with Hispanic- Style Cheese Consumption}

Each year in the United States, approximately 1,600 persons become seriously ill as a result of $L$. monocytogenes infection, and 260 of these persons die due the infection (CDC, 2014a). During the period from 1998 to 2014, 56 confirmed listeriosis outbreaks were recorded, resulting in 707 illnesses, 520 hospitalizations, and 116 deaths (CDC, 2015a). Of these outbreaks, 11 (19.6\%) implicated HSC, comprising 98 illnesses, 60 hospitalizations, and 5 deaths. Although the majority of listeriosis cases affect the elderly (age $\geq 65$ yr; Silk et al., 2012), the greatest risk of listeriosis is shared by pregnant Hispanic women (Pouillot et al., 2012) due to their more frequent consumption of HSC and heightened susceptibility to listerial infection during pregnancy, although socioeconomic factors may contribute as well (Gillespie et al., 2010).

Insufficient pasteurization was the cause of listerial contamination found in the first identified HSC outbreak in the United States. This 1985 outbreak of listeriosis from Mexican-style cheese in Los Angeles County, California, resulted in 142 illnesses and 3 deaths, allegedly from insufficient pasteurization of milk or the introduction of raw milk into pasteurized milk during manufacturing (Linnan et al., 1988). Similarly, between October 2000 and January 2001, a listeriosis outbreak occurred in Winston-Salem, North Carolina, resulting in 13 illnesses, including 5 stillbirths, 3 premature deliveries, and 3 infected newborns. Illnesses were traced to the consumption of Mexican-style cheeses made from contaminated raw milk by unlicensed cheesemakers (MacDonald et al., 2005).

More commonly, however, outbreaks are traced back to the production of fresh cheeses under conditions that allow post-pasteurization contamination from the manufacturing environment, as described above. A 2008-2009 multistate listeriosis outbreak, resulting in 8 illnesses across 5 states, was associated with a Mexican-style cheese manufacturing facility where multiple cheese varieties tested positive for the outbreak strain, suggesting post-pasteurization contamination of pasteurized milk (Jackson et al., 2011). Several other multi-state outbreaks have been linked with HSC recently, resulting in 8 cases and 1 death across 2 states in late 2013 (CDC, 2014b), 5 illnesses and 1 death

Table 5. Occurrence of Listeria monocytogenes isolates from Hispanic-style cheese processing plants

\begin{tabular}{lcl}
\hline Type of sampling site & $\begin{array}{c}\text { Prevalence } \\
\text { (positive samples/total samples) }\end{array}$ & Reference \\
\hline Milk & $0 \%(0 / 47)$ & Moreno-Enriquez et al., 2007 \\
Curds & $0 \%(0 / 16)$ & Rosas-Barbosa et al., 2014 \\
Equipment & $10 \%(3 / 30)$ & Rosas-Barbosa et al., 2014 \\
Food contact surfaces & $19.3 \%(33 / 171)$ & Rosas-Barbosa et al., 2014 \\
& $1.7 \%(2 / 119)$ & Kabuki et al., 2004 \\
Floors & $33.3 \%(10 / 30)$ & Moreno-Enriquez et al., 2007 \\
Cheeses & $29.2 \%(14 / 48)$ & Rosas-Barbosa et al., 2014 \\
& $25.7 \%(19 / 74)$ & Kabuki et al., 2004 \\
Others & $6.3 \%(1 / 16)$ & Rosas-Barbosa et al., 2014 \\
& $6.3 \%(7 / 111)$ & Kabuki et al., 2004 \\
& $3.4 \%(5 / 149)$ & Moreno-Enriquez et al., 2007 \\
& $17.5 \%(11 / 63)$ & Rosas-Barbosa et al., 2014 \\
& $11.3 \%(6 / 53)$ & Kabuki et al., 2004 \\
& $0 \%(0 / 29)$ & Moreno-Enriquez et al., 2007 \\
\end{tabular}


across 4 states through 2014 (CDC, 2014c), and 30 illnesses and 3 deaths in 10 states from the summer of 2010 to 2014 (CDC, 2015b). Strains of Listeria have been traced back to environmental samples from the manufacturing facilities for each of these outbreaks, connecting observations of unsanitary conditions with post-pasteurization contamination of the cheeses. In one of these outbreaks, US Food and Drug Administration inspection reports cited particularly egregious violations, including food residue remaining after cleaning procedures, uncovered storage and transfer containers, deteriorated infrastructure that precluded effective cleaning or sanitation, and water leaking from the roof onto equipment, all of which could facilitate contamination of $L$. monocytogenes after pasteurization (FDA, 2016).

\section{INTERVENTIONS}

Industry and federal guidance documents provide extensive recommendations for the control of L. monocytogenes at the manufacturing level, including facility and equipment design factors, cleaning and sanitation procedures, and environmental and product monitoring techniques, as well as personnel training and food formulation, handling, and storage guidelines (FDA, 2008; IDFA, 2015). Adhering to these standards should minimize opportunities for listerial contamination or growth in HSC manufacturing settings. In practice, however, allowing good manufacturing procedures to remain the primary preservation method for HSC clearly risks insufficient or inconsistent implementation, as described above, resulting in the numerous outbreaks and recalls observed. Although execution of environmental controls for preventing contamination must clearly be improved to adequately address the risks of listerial contamination in many situations, additional interventions and additives have also been sought for the prevention of listerial growth and survival in fresh cheeses.

\section{Antimicrobial Treatments to Reduce $L$. monocytogenes in Hispanic-Style Cheeses}

Relatively few studies have been published on the examination of antimicrobial methods for the preservation of fresh HSC. To date, almost all studies have been carried out using Queso Fresco as an HSC model with L. monocytogenes or Listeria innocua.

High-pressure processing is often used as a final hurdle to preserve packaged ready-to-eat foods such as sausages, so it was understandably investigated to address pathogens in HSC. While pressures of 500 to 600 $\mathrm{MPa}$ can considerably reduce listerial populations in Queso Fresco (>5 log cfu/g), high-pressure processing cannot prevent regrowth of surviving cells (Tomasula et al., 2014; Hnosko et al., 2012) and compromises protein structure and textural properties in the finished products, resulting in negative effects on consumer sensory preferences (Sandra et al., 2004; Hnosko et al., 2012; Van Hekken et al., 2013).

Organic acids, bacteriocins, and other fermentates, as well as combinations thereof, have been assessed as antilisterial agents for Queso Fresco with limited success. Overcoming the instability and low activity of organic acids near the neutral pH of HSC by combining these combinations with the bacteriocin nisin can improve listerial reduction but are generally bacteriostatic at best (Gadotti et al., 2014; Van Tassell et al., 2015), although they may not diminish consumer acceptability. Queso Blanco manufactured with acetic acid and a commercial bacterial fermentate has also been shown to reduce L. monocytogenes by 2 to $3 \mathrm{log} \mathrm{cfu} / \mathrm{g}$ over a 6 -wk shelf life but did not eliminate the pathogen, even at low inoculation levels (Glass et al., 1995). Another promising additive used in meat and poultry-lauric arginate - has been demonstrated to maintain consumer acceptability when applied to Queso Fresco and exhibits moderate reductions in listerial survival (Soni et al., 2010), especially when used in combination with a listerial bacteriophage or a potassium lactate-sodium diacetate mixture (Soni et al., 2012).

Inhibition of surface contamination via antimicrobial packaging materials may also improve protection of HSC, as they have shown promise on meat, produce, and other cheeses (Moreira et al., 2011; Irkin and Esmer, 2015). Edible packaging films of chitosan and lactic acid have been shown to reduce L. monocytogenes on the surface of Queso Fresco, enhancing pathogen inhibition further with the grafting of other components within the films (Sandoval et al., 2016); however, significant moisture loss in the cheeses was observed during storage. Effects on HSC quality by such coatings remain to be seen, as do their effectiveness against nonsurface contaminants, such as those introduced during curd manipulation. For further discussion on the potential and difficulties of antimicrobial food packaging, see Malhotra et al. (2015).

The quest for antilisterial treatments in HSC, illustrated by the aforementioned studies, is characterized by 2 main gaps. First, even though Queso Fresco is the best known HSC in the United States, it is not necessarily representative of all HSC: different manufacturing processes may imply not only different listerial contamination scenarios, but also that antimicrobial treatments may show different efficacy depending on the cheese variety. Additionally, studies have focused primarily on preservation methods less likely to affect the subtle taste and delicate texture of fresh HSC; 
however, confirmation of sensory impact or consumer acceptability is less commonly reported. A food antimicrobial agent should meet 3 important aspects in the food product: (1) its antimicrobial activity should be selective, (2) it should have negligible effect on texture and sensory properties, and (3) it should be safe for human consumption (Oliveira et al., 2012). Therefore, evaluating an antimicrobial with potential application to food industry should not be limited only to its antimicrobial properties.

\section{Cheese Surrogates}

The simplest method for examining the effect of antilisterial treatments for fresh cheeses involves contaminating and treating commercially prepared or otherwise finished cheeses. Several treatments have been tested by taking slices of prepared cheese and applying antimicrobials and L. monocytogenes to the surface, and these have shown effectiveness at reducing bacterial growth over product shelf life (Soni et al., 2010, 2012; Malheiros et al., 2012). This is a quick and effective method for assessing antimicrobial efficacy on finished cheeses but it may offer a narrow view of antimicrobial treatment: antimicrobial interactions are confined to an environment with limited impact by the cheese matrix itself. Homogenization of samples confers greater incorporation of the components into the product, but the disrupted microstructure may poorly reflect the interactions taking place between contaminants and antimicrobials within commercial applications. Unless the antimicrobial treatment is intended solely for external application, its design should consider the logistics of cheesemaking. In this case, laboratory-made cheeses should be preferred over already prepared samples for studying preservatives, to allow for the cheese model to resemble the most appropriate steps for contamination and antimicrobial addition without altering the manufacturing process.

Incorporation of pathogens on a large scale can be cumbersome for maintaining proper biosafety, so these methods often rely on homogenization of the finished cheeses before inoculation, but modifying cheese manufacturing processes or incorporating novel antimicrobials into pilot-scale cheese production to assess the impact on pathogen growth and survival is not unheard of (Kasrazadeh and Genigeorgis, 1995; Bolton and Frank, 1999). Listeria monocytogenes has been shown to survive and grow when incorporated into the production process for soft cheeses under various conditions (Leggett et al., 2012), even when commercial starter cultures are present (Solano-López and Hernández-Sánchez, 2000; Leuschner and Boughtflower, 2002). Screening antimicrobial agents in relatively large batches of cheese can be costly, although combinations of organic acids and nisin have shown to exhibit inhibitory effects (Gadotti et al., 2014). Coelho et al. (2014) used a much smaller batch size $(0.5 \mathrm{~L})$ to assess the antilisterial effects of incorporating bacteriocin-producing cultures into fresh cheeses, which raises the question of what scale is actually necessary for modeling fresh cheese production.

High-throughput, miniaturized cheese manufacturing models have been explored for their use in screening starter cultures and antimicrobials, resulting in cheeses with comparable structure to traditional equivalents despite preparation in 96-well microplates (Bachmann et al., 2009). We recently developed a similar model that now shows promise for screening antimicrobial additives in the production of miniature fresh cheeses (Van Tassell et al., 2015). Such miniaturized cheese models can be adapted to address numerous manufacturing parameters while benefitting from greater replication with minimal capital or resource consumption and improved biosafety management. In this way, antimicrobial treatments can be assessed in situ for intact cheeses under different treatment or contamination scenarios, reflecting commercial applications more appropriately.

Use of a surrogate organism for modeling listerial contamination of cheeses should also be addressed with care. Because of its close phylogenetic relatedness and similar physiology, nonpathogenic $L$. innocua can be used in place of L. monocytogenes for experimental work. However, variations in stress response may result in reactions to different antimicrobials that are not comparable between organisms under different environmental conditions. Therefore, caution should be taken in extrapolating results from the use of a surrogate, and validation with $L$. monocytogenes strains is encouraged for any given application. For a thorough review of this subject, see Milillo et al. (2012).

\section{FUTURE DIRECTIONS}

Relatively little is known about the association of L. monocytogenes with specific varieties of HSC. Most studies approach Queso Fresco as being representative of the category; however, this may not be the case. It is unclear to what extent different manufacturing steps and variations in the finished product affect epidemiologic factors, as our knowledge of L. monocytogenes in commercial products is largely outdated and limited to Queso Fresco, especially in the United States. More current knowledge of incidence, particularly in other varieties of HSC, would be informative for risk analysis and preventative purposes.

Advances in monitoring and sanitation in dairy processing plants may contribute significantly to preventing further outbreaks of listeriosis due to HSC, especially 
considering the proportion of contamination likely due to post-pasteurization contact with environmentally persistent strains. One such area with room for growth involves the use of next-generation sequencing tools for microbial community profiling, such as already demonstrated in some wineries and artisanal cheese producers (Bokulich and Mills, 2013; Bokulich et al., 2016). More thorough knowledge of typical microbial communities and "abnormal" or "unsafe" deviations therefrom could perhaps help track potential sanitation issues and avoid environmental persistence of $L$. monocytogenes.

Furthermore, the extensive exploration of model cheese systems could promote deeper understanding of the interactions between antilisterial treatments, their targets, and food matrices. Such models could similarly facilitate the screening of combinatorial treatments that may exhibit synergistic mechanisms of antimicrobial action and the optimization of application parameters for their use in processing environments. Novel antimicrobials that may function as enhanced food preservatives include bioengineered bacteriophages or phage endolysins (Van Tassell et al., 2016). It would also be necessary, however, to overcome the confines of laboratory testing and confirm efficacy among the complexities of a commercial manufacturing setting.

As more attention is drawn to the field, collaborative and interdisciplinary efforts will ultimately produce a cost-efficient, consumer-friendly solution to effectively limit L. monocytogenes in Hispanic-style cheeses.

\section{REFERENCES}

Adzitey, F., and N. Huda. 2010. Listeria monocytogenes in foods: Incidences and possible control measures. Afr. J. Microbiol. Res. $4: 2848-2855$

Alba, L. A., C. de Staff, C. R. L. Richter, and C. V. Dill. 1990. Mexican Asadero cheese: A survey of its composition. J. Dairy Sci. 73(Suppl. 1):269.

Alcázar Montañez, C. D., M. S. Rubio Lozano, F. Núñez Espinosa and R. A. Alonso Morales. 2006. Detection of Salmonella spp. and Listeria monocytogenes in fresh and semi-cured cheeses that are sold on the street markets in Mexico City. Vet. Mex. 37:417-429.

Bachmann, H., Z. Kruijswijk, D. Molenaar, M. Kleerebezem, and J. E. T. van Hylckama Vlieg. 2009. A high-throughput cheese manufacturing model for effective cheese starter culture screening. J. Dairy Sci. 92:5868-5882.

Batz, M. B., S. Hoffman, and J. G. Morris Jr. 2011. Ranking the risks: The 10 pathogen-food combinations with the greatest burden on public health. Emerging Pathogens Institute, University of Florida, Gainesville.

Batz, M. B., S. Hoffmann, and J. G. Morris Jr. 2012. Ranking the disease burden of 14 pathogens in food sources in the United States using attribution data from outbreak investigations and expert elicitation. J. Food Prot. 75:1278-1291.

Bokulich, N. A., Z. T. Lewis, K. Boundy-Mills, and D. A. Mills. 2016. A new perspective on microbial landscapes within food production. Curr. Opin. Biotechnol. 37:182-189.

Bokulich, N. A., and D. A. Mills. 2013. Facility-specific "house" microbiome drives microbial landscapes of artisan cheesemaking plants. Appl. Environ. Microbiol. 79:5214-5223.
Bolton, L. F., and J. F. Frank. 1999. Defining the growth/no-growth interface for Listeria monocytogenes in Mexican-style cheese based on salt, pH, and moisture content. J. Food Prot. 62:601-609.

Caro, I., S. Soto, L. Fuentes, N. Gutiérrez-Méndez, B. García-Islas, K. E. Monroy-Gayosso, and J. Mateo. 2014. Compositional, functional and sensory characteristics of selected Mexican cheeses. Food Nutr. Sci. 5:366-375.

Castañeda-Ruelas, G., C. Eslava-Campos, N. Castro-del Campo, J. León-Félix, and C. Chaidez-Quiroz. 2014. Listeriosis in Mexico: Clinical and epidemiological importance. Salud Publica Mex. $56: 654-659$.

CDC. 2014a. Listeria (Listeriosis): Statistics. Centers for Disease Control and Prevention. Accessed May 5, 2016. http://www.cdc.gov/ listeria/statistics.html.

CDC. 2014b. Multistate outbreak of listeriosis linked to Roos Foods Dairy Products (Final Update). Centers for Disease Control and Prevention. Accessed May 5, 2016. http://www.cdc.gov/listeria/ outbreaks/cheese-02-14/index.html.

CDC. 2014c. Oasis Brands, Inc. cheese recalls and investigation of human listeriosis cases (Final Update). Centers for Disease Control and Prevention. Accessed May 5, 2016. http://www.cdc.gov/ listeria/outbreaks/cheese-10-14/index.html.

CDC. 2015a. Foodborne outbreak online database (FOOD). Centers for Disease Control and Prevention. Accessed May 5, 2016. http:// wwwn.cdc.gov/foodborneoutbreaks/.

CDC. 2015b. Multistate outbreak of listeriosis linked to soft cheeses distributed by Karoun Dairies Inc. (Final Update). Centers for Disease Control and Prevention. Accessed May 5, 2016. http:// www.cdc.gov/listeria/outbreaks/soft-cheeses-09-15/index.html.

Clark, S., H. Warner, and L. Luedecke. 2001. Acceptability of Queso Fresco cheese by traditional and nontraditional consumers. Food Sci. Technol. Int. 7:165-170.

CMAB. 2016. Real California Cheese processor list January 6, 2016. California Milk Advisory Board. Accessed May 2016.http:// www.realcaliforniamilk.com/wp-content/uploads/Jan2016_RCC_ PL_w-changes_v3.pdf.

Coelho, M. C., C. C. G. Silva, S. C. Ribeiro, M. L. N. E. Dapkevicius, and H. J. D. Rosa. 2014. Control of Listeria monocytogenes in fresh cheese using protective lactic acid bacteria. Int. J. Food Microbiol 191:53-59

FDA. 2008. Guidance for industry: control of Listeria monocytogenes in refrigerated or frozen ready-to-eat foods; draft guidance. Food and Drug Administration. Accessed Nov. 30, 2016. http://www.fda.gov/Food/ GuidanceRegulation/GuidanceDocumentsRegulatoryInformation/ FoodProcessingHACCP/ucm073110.htm.

FDA. 2015. The dangers of raw milk: Unpasteurized milk can pose a serious health risk. Food and Drug Administration. Accessed May 5, 2016. http://www.fda.gov/Food/ResourcesForYou/Consumers/ ucm079516.htm.

FDA. 2016. FDA investigates presence of Listeria in some Hispanicstyle cheeses. Food and Drug Administration. Accessed Nov. 30 2016. http://www.fda.gov/Food/RecallsOutbreaksEmergencies/ Outbreaks/ucm386726.htm.

Fernandez Escartin, E. 2008. Microbiología e Inocuidad de los Alimentos. 2a Ed. Universidad Autónoma de Querétaro, México.

Ferreira, V., M. Wiedmann, P. Teixeira, and M. J. Stasiewicz. 2014. Listeria monocytogenes persistence in food associated environments: Epidemiology, strain characteristics, and implications for public health. J. Food Prot. 77:150-170.

Fuentes, L., J. Mateo, E. J. Quinto, and I. Caro. 2015. Changes in quality of nonaged pasta filata Mexican cheese during refrigerated vacuum storage. J. Dairy Sci. 98:2833-2842.

Gadotti, C., L. Nelson, and F. Diez-Gonzalez. 2014. Inhibitory effect of combinations of caprylic acid and nisin on Listeria monocytogenes in queso fresco. Food Microbiol. 39:1-6.

Genigeorgis, C., M. Carniciu, D. Dutulescu, and T. B. Farver. 1991a Growth and survival of Listeria monocytogenes in market cheeses stored at 4 to $30^{\circ} \mathrm{C}$. J. Food Prot. 54:662-668.

Genigeorgis, C., J. H. Toledo, and F. J. Garayzabal. 1991b. Selected microbiological and chemical characteristics of illegally produced 
and marketed soft Hispanic-style cheeses in California. J. Food Prot. 54:598-601.

Gillespie, I. A., P. Mook, C. L. Little, K. A. Grant, and J. McLauchlin. 2010. Human listeriosis in England, 2001-2007: association with neighbourhood deprivation. Euro Surveill. 15:7-16.

Glass, K. A., B. B. Prasad, J. H. Schlyter, H. E. Uljas, N. Y. Farkye, and J. B. Luchansky. 1995. Effects of acid type and ALTA ${ }^{\mathrm{TM}} 2341$ on Listeria monocytogenes in a Queso Blanco type of cheese. J. Food Prot. 58:737-741.

Gombas, D. E., Y. Chen, R. S. Clavero, and V. N. Scott. 2003. Survey of Listeria monocytogenes in ready-to-eat foods. J. Food Prot. 66:559-569.

González-Córdova, A. F., C. Yescas, A. M. Ortiz-Estrada, M. A. De la Rosa-Alcaraz, A. Hernández-Mendoza, and B. Vallejo-Cordoba. 2016. Invited review: Artisanal Mexican cheeses. J. Dairy Sci. 99:3250-3262.

Gould, L. H., E. Mungai, and C. Barton Behravesh. 2014. Outbreaks attributed to cheese: Differences between outbreaks caused by unpasteurized and pasteurized dairy products, United States, 19982011. Foodborne Pathog. Dis. 11:545-551.

Hernández-Morales, C., A. Hernández-Montes, E. Aguirre-Mandujano, and A. Villegas de Gante. 2010. Physicochemical, microbiological, textural and sensory characterisation of Mexican Añejo cheese. Int. J. Dairy Technol. 63:552-560.

Hernández Morales, C., A. Hernández Montes, A. Z. Villegas de Gante, and E. Aguirre Mandujano. 2011. Socio-technical production process of Zacazonapan Añejo cheese, a traditional cheese from the State of Mexico. Rev. Mex. De Cienc. Pecu. 2:161-176.

Hnosko, J., S. Clark, and D. Van Hekken. 2009. Latin American Cheeses. Pages 489-504 in The Sensory Evaluation of Dairy Products. S. Clark, M. Costello, M. Drake, and F. Bodyfelt, ed. Springer, New York, NY.

Hnosko, J., M. F. San-Martin Gonzalez, and S. Clark. 2012. Highpressure processing inactivates Listeria innocua yet compromises Queso Fresco crumbling properties. J. Dairy Sci. 95:4851-4862.

Hussain, M., and C. Dawson. 2013. Economic impact of food safety outbreaks on food businesses. Foods 2:585-589.

IDFA. 2015. Control of Listeria monocytogenes: Guidance for the U.S. dairy industry. International Dairy Food Association, Washington, DC.

ILSI (ILSI Research Foundation and Risk Science Institute). 2005. Achieving continuous improvement in reduction in foodborne listeriosis - A risk-based approach. J. Food Prot. 68:1932-1994.

Irkin, R., and O. K. Esmer. 2015. Novel food packaging systems with natural antimicrobial agents. J. Food Sci. Technol. 52:6095-6111.

Jackson, B. R., C. Tarr, E. Strain, K. A. Jackson, A. Conrad, H. Carleton, L. S. Katz, S. Stroika, L. H. Gould, R. K. Mody, B. J. Silk, J. Beal, Y. Chen, R. Timme, M. Doyle, A. Fields, M. Wise, G. Tillman, S. Defibaugh-Chavez, Z. Kucerova, A. Sabol, K. Roache, E. Trees, M. Simmons, J. Wasilenko, K. Kubota, H. Pouseele, W. Klimke, J. Besser, E. Brown, M. Allard, and P. Gerner-Smidt. 2016. Implementation of nationwide real-time whole-genome sequencing to enhance listeriosis outbreak detection and investigation. Clin. Infect. Dis. 63:380-386.

Jackson, K. A., M. Biggerstaff, M. Tobin-D'Angelo, D. Sweat, R. Klos, J. Norari, O. Garrison, E. Boothe, L. Saathoff-Huber, L. Hainstock, and R. P. Fagan. 2011. Multistate outbreak of Listeria monocytogenes associated with Mexican-style cheese made from pasteurized milk among pregnant, Hispanic women. J. Food Prot. 74:949-953.

Kabuki, D. Y., A. Y. Kuaye, M. Wiedmann, and K. J. Boor. 2004. Molecular subtyping and tracking of Listeria monocytogenes in Latinstyle fresh-cheese processing plants. J. Dairy Sci. 87:2803-2812.

Kasrazadeh, M., and C. Genigeorgis. 1995. Potential growth and control of Escherichia coli O157:H7 in soft Hispanic type cheese. Int. J. Food Microbiol. 25:289-300.

Kilonzo-Nthenge, A., F.-C. Chen, and S. L. Godwin. 2008. Occurrence of Listeria and Enterobacteriaceae in domestic refrigerators. J. Food Prot. 71:608-612.

Kinde, H., A. Mikolon, A. Rodriguez-Lainz, C. Adams, R. L. Walker, S. Cernek-Hoskins, S. Treviso, M. Ginsberg, R. Rast, B. Harris,
J. B. Payeur, S. Waterman, and A. Ardans. 2007. Recovery of Salmonella, Listeria monocytogenes, and Mycobacterium bovis from cheese entering the United States through a noncommercial land port of entry. J. Food Prot. 70:47-52.

Leggett, L. N., P. M. Tomasula, D. L. Van Hekken, A. C. S. PortoFett, B. Shoyer, J. A. Renye, J. B. Luchansky, and N. Farkye. 2012. Effect of storage at 4 and $10^{\circ} \mathrm{C}$ on the growth of Listeria monocytogenes in and on Queso Fresco. J. Food Saf. 32:236-245.

Leong, W. M., R. Geier, S. Engstrom, S. Ingham, B. Ingham, and M. Smukowski. 2014. Growth of Listeria monocytogenes, Salmonella spp., Escherichia coli O157:H7, and Staphylococcus aureus on cheese during extended storage at $25^{\circ} \mathrm{C}$. J. Food Prot. 77:12751288 .

Leuschner, R. G. K., and M. P. Boughtflower. 2002. Laboratory-scale preparation of soft cheese artificially contaminated with low levels of Escherichia coli O157, Listeria monocytogenes, and Salmonella enterica serovars Typhimurium, Enteritidis, and Dublin. J. Food Prot. 65:508-514.

Linnan, M. J., L. Mascola, X. D. Lou, V. Goulet, S. May, C. Salminen, D. W. Hird, M. L. Yokenura, P. Hayes, R. Weaver, A. Audurier, B. D. Plikaytis, S. L. Fannin, A. Kleks, and C. V. Broome. 1988. Epidemic listeriosis associated with Mexican-style cheese. N. Engl. J. Med. 319:823-828.

MacDonald, P. D. M., R. E. Whitwam, J. D. Boggs, J. N. MacCormack, K. L. Anderson, J. W. Reardon, J. R. Saah, L. M. Graves, S. B. Hunter, and J. Sobel. 2005. Outbreak of listeriosis among Mexican immigrants as a result of consumption of illicitly produced Mexican-style cheese. Clin. Infect. Dis. 40:677-682.

Macías-Rodríguez, M. E., V. Navarro-Hidalgo, J. R. Linares-Morales, M. A. Olea-Rodríguez, A. Villarruel-López, J. Castro-Rosas, C. A. Gómez-Aldapa, and M. R. Torres-Vitela. 2013. Microbiological safety of domestic refrigerators and the dishcloths used to clean them in Guadalajara, Jalisco, Mexico. J. Food Prot. 76:984-990.

Malheiros, P. da S., D. J. Daroit, and A. Brandelli. 2012. Inhibition of Listeria monocytogenes in Minas Frescal cheese by free and nanovesicle-encapsulated nisin. Braz. J. Microbiol. 43:1414-1418.

Malhotra, B., A. Keshwani, and H. Kharkwal. 2015. Antimicrobial food packaging: Potential and pitfalls. Front. Microbiol. 6:611.

Milillo, S. R., E. C. Friedly, J. C. Saldivar, A. Muthaiyan, C. O’Bryan, P. G. Crandall, M. G. Johnson, and S. C. Ricke. 2012. A review of the ecology, genomics, and stress response of Listeria innocua and Listeria monocytogenes. Crit. Rev. Food Sci. Nutr. 52:712-725.

Moreira, M. del R., M. Pereda, N. E. Marcovich, and S. I. Roura. 2011. Antimicrobial effectiveness of bioactive packaging materials from edible chitosan and casein polymers: Assessment on carrot, cheese, and salami. J. Food Sci. 76:M54-M63.

Moreno-Enriquez, R. I., A. Garcia-Galaz, E. Acedo-Felix, H. Gonzalez-Rios, J. E. Call, J. B. Luchansky, and M. E. Diaz-Cinco. 2007. Prevalence, types, and geographical distribution of Listeria monocytogenes from a survey of retail Queso Fresco and associated cheese processing plants and dairy farms in Sonora, Mexico. J. Food Prot. 70:2596-2601.

Oliveira, H., J. Azeredo, R. Lavigne, and L. D. Kluskens. 2012. Bacteriophage endolysins as a response to emerging foodborne pathogens. Trends Food Sci. Technol. 28:103-115.

Olson, D. W., D. L. Van Hekken, M. H. Tunick, P. M. Tomasula, F. J. Molina-Corral, and A. A. Gardea. 2011. Mexican Queso Chihuahua: Functional properties of aging cheese. J. Dairy Sci. 94:4292-4299.

Pouillot, R., K. Hoelzer, K. A. Jackson, O. L. Henao, and B. J. Silk. 2012. Relative risk of listeriosis in Foodborne Diseases Active Surveillance Network (FoodNet) sites according to age, pregnancy, and ethnicity. Clin. Infect. Dis. 54:S405-S410.

Rosas-Barbosa, B.T., A. Luis-Juan Morales, R. Alaniz-de la O, A. Ramírez-Álvarez, J.P. Soltero-Ramos, R. de la Mora-Quiroz, P. Martin, and C. Jacquet. 2014. Presence and persistence of Listeria in four artisanal cheese plants in Jalisco, Mexico. e-Cucba 2:3-37.

Ryser, E. T. 2007. Incidence and behavior of Listeria monocytogenes in cheese and other fermented dairy products. Pages 405-501 in Listeria, Listeriosis and Food Safety. E. T. Ryser, and E. H. Marth, ed. Taylor \& Francis Group LLC, Boca Raton, FL. 
Saltijeral, J. A., V. B. Alvarez, and B. Garcia. 1999. Presence of Listeria in Mexican cheeses. J. Food Saf. 19:241-247.

Sandoval, L. N., M. López, E. Montes-Díaz, A. Espadín, A. Tecante, M. Gimeno, and K. Shirai. 2016. Inhibition of Listeria monocytogenes in fresh cheese using chitosan-grafted lactic acid packaging. Molecules 21:469. https://doi.org/10.3390/molecules21040469.

Sandra, S., M. A. Stanford, and L. Meunier Goddik. 2004. The use of high-pressure processing in the production of Queso Fresco cheese. J. Food Sci. 69:153-158.

Silk, B. J., K. A. Date, K. A. Jackson, R. Pouillot, K. G. Holt, L. M. Graves, K. L. Ong, S. Hurd, R. Meyer, R. Marcus, B. Shiferaw, D. M. Norton, C. Medus, S. M. Zansky, A. B. Cronquist, O. L. Henao, T. F. Jones, D. J. Vugia, M. M. Farley, and B. E. Mahon. 2012. Invasive listeriosis in the Foodborne Diseases Active Surveillance Network (FoodNet), 2004-2009: Further targeted prevention needed for higher-risk groups. Clin. Infect. Dis. 54:S396-S404.

Solano-López, C., and H. Hernández-Sánchez. 2000. Behaviour of Listeria monocytogenes during the manufacture and ripening of Manchego and Chihuahua Mexican cheeses. Int. J. Food Microbiol. 62:149-153.

Solís-Méndez, A. D., J. G. Estrada-Flores, and O. A. Castelán-Ortega. 2013. A study on the texture diversity of the Artisan Ranchero cheese from Central Mexico. Int. J. Dairy Technol. 66:37-44.

Soni, K. A., M. Desai, A. Oladunjoye, F. Skrobot, and R. Nannapaneni. 2012. Reduction of Listeria monocytogenes in Queso Fresco cheese by a combination of listericidal and listeriostatic GRAS antimicrobials. Int. J. Food Microbiol. 155:82-88.

Soni, K. A., R. Nannapaneni, M. W. Schilling, and V. Jackson. 2010. Bactericidal activity of lauric arginate in milk and Queso Fresco cheese against Listeria monocytogenes cold growth. J. Dairy Sci. 93:4518-4525.

Soto Beltran, M., C. P. Gerba, A. Porto Fett, J. B. Luchansky, and C. Chaidez. 2015. Prevalence and characterization of Listeria monocytogenes, Salmonella and Shiga toxin-producing Escherichia coli isolated from small Mexican retail markets of Queso Fresco. Int. J. Environ. Health Res. 25:140-148.

Stasiewicz, M. J., H. F. Oliver, M. Wiedmann, and H. C. den Bakker. 2015. Whole genome sequencing allows for improved identification of persistent Listeria monocytogenes in food associated environments. Appl. Environ. Microbiol. 81:6024-6037.

Tomasula, P. M., J. A. Renye, D. L. Van Hekken, M. H. Tunick, R. Kwoczak, M. Toht, L. N. Leggett, J. B. Luchansky, A. C. S. PortoFett, and J. G. Phillips. 2014. Effect of high-pressure processing on reduction of Listeria monocytogenes in packaged Queso Fresco. J. Dairy Sci. 97:1281-1295.

Torres-Llanez, M. J., B. Vallejo-Cordoba, M. E. Díaz-Cinco, M. A. Mazorra-Manzano, and A. F. González-Córdova. 2006. Characterization of the natural microflora of artisanal Mexican Fresco cheese. Food Contr. 17:683-690.

Torres-Vitela, M. R., M. Mendoza-Bernardo, J. Castro-Rosas, C. A. Gomez-Aldapa, L. E. Garay-Martinez, V. Navarro-Hidalgo, and A. Villarruel-López. 2012. Incidence of Salmonella, Listeria monocytogenes, Escherichia coli O157:H7, and staphylococcal enterotoxin in two types of Mexican fresh cheeses. J. Food Prot. 75:79-84.

Tunick, M. H., and D. L. Van Hekken. 2010. Rheology and texture of commercial Queso Fresco cheeses made from raw and pasteurized milk. J. Food Qual. 33(Suppl. 1):204-215.

Tunick, M. H., D. L. Van Hekken, S. K. Iandola, and P. M. Tomasula. 2012. Characterization of Queso Fresco during storage at 4 and $10^{\circ}$ C. J. Food Res. 1:308-319.
Uhlich, G. A., J. B. Luchansky, M. L. Tamplin, F. J. Molina-Corral, S. Anandan, and A. C. S. Porto-Fett. 2006. Effect of storage temperature on the growth of Listeria monocytogenes on Queso Blanco slices. J. Food Saf. 26:202-214.

US Census Bureau. 1997. The Hispanic Population in the United States: March 1996 (Update). Accessed May 2016. http://www. census.gov/prod/3/97pubs/p20-502.pdf.

US Census Bureau. 2015. Facts for Features: Hispanic Heritage Month 2015. https://www.census.gov/newsroom/facts-for-features/2015/ cb15-ff18.html. May 2016.

USDA-ERS. 2015. Per capita consumption of selected cheese varieties (Annual) September 2015. United States Department of Agriculture-Economic Research Service. http://www.ers.usda.gov/ data-products/dairy-data.aspx. May 2016.

USDA-FSIS. 2003. Quantitative assessment of relative risk to public health from foodborne Listeria monocytogenes among selected categories of ready-to-eat foods. United Stated Department of Agriculture-Food Safety and Inspection Service. Accessed August 2016. http://www.fda.gov/downloads/Food/ FoodScienceResearch/UCM197330.pdf.

USDA-NASS. 1997. Dairy products 1996 summary. United States Department of Agriculture-National Agricultural Statistics Service. Accessed May 2016. http://usda.mannlib.cornell.edu/usda/nass/ DairProdSu//1990s/1997/DairProdSu-05-06-1997.pdf.

USDA-NASS. 2015. Quick stats (database). United States Department of Agriculture-National Agricultural Statistics Service. Accessed May 2016. https://quickstats.nass.usda.gov/.

USDA-NASS. 2016. Dairy products 2015 summary. United States Department of Agriculture-National Agricultural Statistics Service. Accessed August 2016. http://usda.mannlib.cornell.edu/ usda/current/DairProdSu/DairProdSu-04-28-2016.pdf.

Van Hekken, D. L., M. H. Tunick, N. Y. Farkye, and P. M. Tomasula. 2013. Effect of hydrostatic high-pressure processing on the chemical, functional, and rheological properties of starter-free Queso Fresco. J. Dairy Sci. 96:6147-6160.

Van Hekken, D. L., M. H. Tunick, L. N. Legget, and P. M. Tomasula. 2012. Impact of curd milling on the chemical, functional, and rheological properties of starter-free Queso Fresco. J. Dairy Sci. 95:5527-5535.

Van Hekken, D. L., M. H. Tunick, P. M. Tomasula, F. J. Molina Coral, and A. A. Gardea. 2007. Mexican Queso Chihuahua: Rheology of fresh cheese. Int. J. Dairy Technol. 60:5-12.

Van Tassell, M. L., M. A. Daum, J. S. Kim, and M. J. Miller. 2016. Creative lysins: Listeria and the engineering of antimicrobial enzymes. Curr. Opin. Biotechnol. 37:88-96.

Van Tassell, M. L., L. A. Ibarra-Sánchez, S. R. Takhar, S. L. AmayaLlano, and M. J. Miller. 2015. Use of a miniature laboratory fresh cheese model for investigating antimicrobial activities. J. Dairy Sci. 98:8515-8524.

Villegas de Gante, A. 2004. Pages 242-369 in Tecnología Quesera. Editorial Trillas, México.

Villegas de Gante, A. Z., and D. Messner Guillen. 2015. Use of sodium citrate in Asadero cheese-making. Ingeniería Agrícola y Biosistemas 7:35-47.

Yang, H., A. Mokhtari, L.-A. Jaykus, R. A. Morales, S. C. Cates, and P. Cowen. 2006. Consumer phase risk assessment for Listeria monocytogenes in deli meats. Risk Anal. 26:89-103. 